\title{
Translating Children's Literature between Indian Languages: A Case for Critical Understanding of Indian Children's Literature
}

Pramod PAdWAl \& Umesh Kumar. (trans. \& eds.). 2019, Kisson Ki Duniya. Marathi Bal Kahaniyon Ka Pratinidhi Sankalan. New Delhi: Vani Prakshan.

Reviewed by SUJIT R. CHANDAK

Translation in the Indian context is usually seen as translation from the English language to the Indian languages and viceversa. Translation and the related movement of literature, contexts and cultural significances from one Indian language to other Indian languages are not that common. There are some translations but translation from one to another Indian language is not a 'regular' activity. This lack is more evident in the case of Children's Literature; coupled with this is the fact that there is a lack of academic attention towards the genre of 'Children's Literature' in the Indian languages. So much so that while considering the category of children's Literature the Indian academia necessarily keeps in mind the development in the notion of the 'child' in the western world and at the same time, although it has the understanding for the need of critically differentiating the way in which the child was constructed in the Indian context, it is hindered by the dearth of critical studies of Children's Literature in the Indian languages. It finds itself restricted in having a critical understanding of the child and of 'Children's Literature' in India as there has been a lack of any serious and continued interest in studying Indian Children's Literature. One prime reason for the insufficiency of a critical understanding of the child in literary texts is an absence of translation of Children's Literature between Indian languages. Hence, this book Kisson Ki Duniya which contains translation of Children's Literature 
(short stories \& short character sketches) from the Marathi language into the Hindi language is relevant and timely.

Pramod Padwal and Umesh Kumar, the translators and editors of the book, Kisson Ki Duniya, aim to fulfil the lack of translation between Indian Languages. It present an opportunity for adding literary pieces from different Indian languages in the language textbooks of other Indian languages, which enable possibilities for installing comparative approach of understanding Indian Literature at the school level that could arrest the narrowness of thought process which is a wider pedagogical problem being faced in India. They aim to do this work by including short stories across the spectrum of over hundred years of the rich tradition of publications for children in Marathi and by including inspiring character sketches of great historical figures of Maharashtra that have inspired generations of Marathi populace.

The translations of the Marathi short stories and character sketches into Hindi presented in the book have a natural flow. The Maharashtrian cultural context is very aptly and smoothly presented in Hindi. While reading the short stories in Hindi one does not feel in any way being distanced by the cultural context. For the readers in Hindi there are no jerks and the translation is evidently successful as it does not make the reader feel that they are reading a work in translation. The stories deal with the everyday world of the children and their approach, mentality and psychology of dealing with the dayto-day affairs are the subject matter of these stories. Stories such as 'Gachak Andhari', 'Namak ki khoj' and 'Chatur Kisan' are uniquely creative pieces that would be of great interest to Hindi readers; these stories create imaginary situations that have a captivating power to engage the minds of children and young adults. 'Chhota Recharge', 'Aaba ki Kahani', 'Main Amir hun' and 'Vidyalay ke Din' present the 
world of the school and the events that take place therein. These stories not just bring out the inherent innocence of childhood but also the self-respecting and resilient nature of children in hardship. Other stories present the innocence and the truthfulness of children and the way the adult world often has a misunderstanding about these issues. Among the character sketches, some figures are generally known across India. However, the stories of some others are not that well known, particularly the character sketches of Sant Gadge Baba, Khashaba Jadhav, Sane Guruji, Rajashri Sahu Maharaj will be of special interest to the Hindi readers.

The book is subtitled 'A Representative Anthology of Children's Literature in Marathi'. However, the translators and editors have made it clear that the book does not follow any chronological or formal structure in selection of the stories. Hence, it can safely be said that it is 'randomly' representative of the flow of Children's Literature in Marathi. There are 13 stories and 11 inspiring character sketches of great figures. All the short stories chosen present various aspects of children's world from both urban and rural parts of Maharashtra. Out of the 13 authors of the selected short stories only 3 are born in pre-independence India, at least 3 authors are born in post1975. The stories by 3 writers born in pre-independent India have a modern outlook and focus on the basic and raw emotions and turmoil that children face. All the short stories hence are contemporary and would be of great interest to children and the young adults. The book also includes pieces that are not originally in Marathi - one short story by Sudha Murthy and at least one character sketch by A. P. J. Abdul Kalam. The reason for including these in a 'Representative anthology' of Marathi is a bit cryptic on the part of the editors. Similarly, there are 3 character sketches (Graham Bell, Stephen Hawking, A. P. J. Abdul Kalam) which are not the figures from Maharashtra. May be the editors felt that there are 
no good writings in Hindi on these topics and included it; one felt that this space could have been given to contexts and figures from Maharashtra. Every story as well as character sketch has been fore-grounded by providing a short introduction to the context. It would have helped propel the scholarship in this area if the editors would have attempted to provide the year and place where these works appeared for the first time.

The book has a foreword by eminent scholar Maya Pandit, a great translator and someone who has large body of work in translation from Marathi. This foreword presents some of the thoughts of Maya Pandit on translation and interesting aspects of children's literature in itself and its development in Marathi. This immensely adds to the value of the book. Pramod Padwal and Umesh Kumar's ideas on translation and the ways in which they link the importance of translation of Children's Literature with the need for introducing primarily a comparative methodology in the pedagogical practices at school level in India is presented in the translator's note. Both the editors present a case for comparative method in pedagogy and argue that such a method will work as a break on the narrowness that has crept into the educational set-up. They bring out the need to include more material in the language textbooks from contexts outside the native one in a multicultural, multi-lingual country like India.

The book successfully does what it sets out by providing a range of Children's Literature pieces from Marathi to the Hindi readers. It certainly presents an opportunity for Hindi language textbooks and ready material for the important work for including in the Indian language textbooks, material from diverse cultural contexts. It also works as a starting point for discussions on comparative methods. This is an important book for it presents to the Hindi consumers of Children's 
Literature a different world from within the country and it makes a case for more such translations.

***

\section{Cite this Work:}

Chandak, SuJIT R. (interv.). 2020. Translating Children's Literature between Indian Languages: A Case for Critical Understanding of Indian Children's Literature. Translation Today, Vol. 14(2). 212-225. DOI:10.46623/tt/2020.14.2.br2 